\title{
POSTHUMANISMIN PUOLUSTUS
}

\section{KAROLIINA LUMMAA}

Sami Pihlströmin kirjoitus "Transsendentaalinen humanismi" on tervetullut keskustelunavaus humanismin nykymerkityksistä. Pihlströmin mukaan ihmistä ja ihmisyyttä koskevan ajattelun ihmiskeskeisyys on välttämätöntä kahdessa mielessä: emme voi ajatella ja kokea muuten kuin ihmiskeskeisesti, koska olemme ihmisiä, ja vain ihmiskeskeisesti ajatellen voimme vastata kohtaamiimme ongelmiin - myös luontosuhdettamme ja ympäristön tilaa koskeviin. Antaessaan puolustamalleen humanismin muodolle määreen "transsendentaalinen", Pihlström viittaa Immanuel Kantin filosofiaan ja sen laajasti hyväksyttyyn periaatteeseen, että kokemuksella on tietyt transsendentaaliset, siis kokemuksen piirin ylittävät ja välttämättömät ennakkoehtonsa. Pihlström myös pitää itsestään selvänä, että tällöin on kyse nimenomaan ihmisen kokemuksesta. Pihlström kirjoittaa erityisesti humanismin ja ympäristökriisin suhteesta, mutta hän mainitsee myös sosiaalisen eriarvoisuuden, poliittiset kriisit ja "totuudenjälkeisen ajan" tämänhetkisinä haasteina, joita vasten humanismi ja sen kritiikki piirtyvät.

Transsendentaalista humanismia haastavat erilaiset anti-, post- ja transhumanismit, joita Pihlström kutsuu "muodikkaiksi" ja "trendikkäiksi" asettaen ne vastakkain humanismin perinteen kanssa. Tämä on tehokas retorinen keino, jolla luodaan vaikutelma ohimenevästä ilmiöstä, joka ei kosketa, saati horjuta ihmisen ja ihmisyyden filosofian pysyvää perustaa. Pihlström arvelee, että humanismia ja sen haastavia suuntauksia koskeva keskustelu on pysynyt sekavana, koska humanismia ei ole mär̈itelty täsmällisesti tai humanismin käsitettä on jopa käytetty "aivan mielivaltaisin tavoin." Tästä olen samaa mieltä. Toisaalta ajattelen, ettei humanismin, antihumanismin, posthumanismin ja transhumanismin suhteista edelleenkään käydä kootusti sellaista keskustelua, jossa nämä kaikki käsitteet olisi riittävällä tavalla määritelty ja suhteutettu toisiinsa. Kritiikkiä esitetään puolin ja toisin, mutta tasapainoinen vertaileva tarkastelu humanismin eri muotojen ja sen haastajien välillä vaikuttaisi meiltä vielä puuttuvan.

Pihlström on kannassaan selvä:"On hyvin harhaanjohtavaa asettaa humanismi samanarvoiseksi vaihtoehdoksi anti-, post- ja muiden ei-humanismien rinnalle." Pyrin seuraavassa hahmottelemaan humanismikeskustelua siten, että poissulkevaa valintaa ei tarvitsisi tehdä eikä erilaisia humanismin tulkintoja arvottaa suhteessa toisiinsa. Esimerkiksi ihmisarvo, jonka kiistattomuudesta Pihlström niin hienosti kirjoittaa, on nähdäkseni keskeinen eettinen periaate ainakin missä tahansa niistä posthumanistisista suuntauksista, joita itse tunnen.

Haluni reagoida Pihlströmin kirjoitukseen liittyy omiin posthumanismia kohtaan tuntemiini epävarmuuksiin humanistiseen ympäristö- ja eläintutkimukseen perehtyneenä kirjallisuudentutkijana, joka on perustanut väitöskirjansa (2010) ja kaiken sen jälkeisen tutkimuksensa posthumanistiseen ajatteluun. Pyrin osoittamaan, että ongelmistaan huolimatta posthumanismia ei tule Pihlströmin tapaan leimata "lyhytnäköiseksi sekaannukseksi", "väärässä olevaksi" sekä "mielettömäksi 
ja ihmiselle mahdottomaksi”. Tulen Pihlströmin tavoin puhumaan yksinkertaistaen humanismista ja posthumanismista selventääkseni eroavuuksia Pihlströmin muotoileman transsendentaalisen humanismin ja posthumanististen näkemysten välillä. Humanistiset ja posthumanistiset painotukset voivat nähdäkseni olla rinnakkain, jopa yhden yksittäisen tutkijan työssä vaikuttavana jännitteenä. Tällaista kantaa voidaan tietysti pitää ristiriitaisena ja epäloogisena. Jos humanismi on nyt sellaisessa murroksessa, jossa Pihlströmkin esittää sen olevan, on mielestäni selvää, että humanistiset ja posthumanistiset juonteet limittyvät ja sekoittuvat humanisteiksi ja posthumanisteiksi tunnustautuvien mielissä - ja niidenkin, jotka asemoivat ajatteluaan toisin ismein tai ismeittä.

\section{MITÄ POSTHUMANISMI ON?}

Pihlströmin kirjoituksessa humanismia haastavien suuntausten eli antihumanismin, posthumanismin ja transhumanismin keskinäisiä suhteita ja eroja ei juurikaan tarkastella. Keskityn itsekin käsittelemään posthumanismia humanismille antagonistisena ajattelutapana, jonka voisi tiivistetysti määritellä ihmisen olemuksen ja aseman kriittiseksi tarkasteluksi. Posthumanismin ytimessä on kysymys ihmisen suhteesta muihin elollisiin ja elottomiin olioihin sekä näiden suhteiden eettisistä ja käytännöllisistä ulottuvuuksista. (Ks. Lummaa \& Rojola 2014.) Pihlström hyökkää seuraavassa suoraan tällaisia kysymyksenasetteluja vastaan:

"Kuvitelma ihmisen ja muiden luonnonolioiden tasavertaisista suhteista on humanismin näkökulmasta inhimillisen vastuun pakenemista, vain ihmiselle kuuluvan normatiivisen arvioinnin mahdollisuuden hämärtämistä - ja tällaisena ei ainoastaan syvällisesti virheellistä vaan jopa mieletöntä, eräänlainen yritys astua ihmisen tilasta johonkin toisenlaiseen tilaan, jota ei ole meille tarjolla."

Posthumanistinen ajattelu tiivistyy ja samalla yksinkertaistuu yllä näkemykseksi, jonka mukaan oliot ovat lähtökohtaisesti tasavertaisia. Tasavertaisuusnäkökulman rinnalla ja siihen elimellisesti liittyen Pihlström arvostelee posthumanismia ei-inhimillisen toimijuuden ajatuksesta. Hän kiittelee taannoin Tiede E edistyksessä (2/2019) julkaistua Ruuskan, Wilénin ja Heikkurisen artikkelia, jossa arvostellaan posthumanismia "vääränlaisesta toimijuuden attribuoinnista ei-inhimillisille olennoille ja siten sen hämärtämisestä, että esimerkiksi ilmastonmuutoksesta on vastuussa nimenomaan ihminen". Keskeisin ongelma posthumanismissa on siis sen väitetty kykenemättömyys erotella toimijoita toisistaan vaikutusten tai moraalisten ominaisuuksien perusteella. Ruuskaa, Wiléniä ja Heikkurista $(2019,142)$ lainaten: "posthumanistisissa näkökulmissa piilee omat ongelmansa erityisesti liittyen kysymyksiin syy-seuraussuhteista, vastuusta ja toimijuuksista."

Myönnän, että osa posthumanistisesta tutkimuksesta voi joskus olla epätarkasti kirjoitettua: ei-inhimillisten vaikutuksia ja merkityksiä jäljittäessään se ei ehkä tartu kysymyksiin ihmisen toimijuudesta ja vallasta tarpeellisella tarkkuudella (voisin poimia esimerkkejä omista julkaisuistani). Jokainen tietämäni järjestelmällisemmin kehitelty posthumanistinen (tai sellaiseksi tulkittava) teoria, esimerkiksi Donna Harawayn, Bruno Latourin, Karen Baradin, Cary Wolfen tai Gilles Deleuzen ja Félix Guattarin filosofia, sisältää kuitenkin tarkkoja, kuvausvoimaisia käsitteellisiä välineitä ihmisen toiminnan ja vallan kriittiseen ja eettiseen tarkasteluun, olipa kyse ihmislajin suhteesta muihin lajeihin, ihmisyhteisön keskinäisistä suhteista tai vaikkapa tieteellisestä tai filosofisesta tutkimuksesta vallankäyttönä.

Siitä huolimatta, että erilaisia ja toisiinsa nähden jännitteisiä posthumanistisia suuntauksia on paljon, niitä yhdistää nähdäkseni se 
perusajatus, että ihminen ei tee eikä ole mitään irrallaan ei-inhimillisistä olioista, ilmiöistä ja prosesseista. Toki ihminen on lajeista se, joka kokonaisvaltaisimmin jäsentää ja muokkaa itseään ja ympäristöään. Silti kaikki nämä jäsentämisen ja muokkaamisen semioottiset ja materiaaliset välineet ovat kehittyneet lajienvälisesti ja yhteydessä orgaaniseen ja eiorgaaniseen. Kielen ja käsitteiden merkitysten ja käytön perusta on ihmisen ja ympäristön vastavuoroisessa suhteessa. Ymmärrys ihmisyksilöiden ja ihmisyhteisöjen mahdollisuuksista ja rajoitteista on aina ympäröivien luonnonolosuhteiden muovaamaa. Käytännölliset keinot luonnonvarojen hyödyntämiseen ovat muokanneet ja muokkaavat kulttuureja,jolloin kulttuurien piirteitä ei voi tarkastella irrallaan niiden ei-inhimillisistä tai materiaalisista reunaehdoista.

Kun Pihlström kysyy kirjoituksensa ensimmäisessä alaotsikossa "Mitä on ihminen?" ja vastaa kysymykseensä leikaten ihmisen erilliseksi muusta maailmasta, hän muotoilee sellaisen ihmiskäsityksen, jota posthumanismi ei yksinkertaisesti jaa. Posthumanistisesta näkökulmasta tarkasteltuna Pihlströmin transsendentaalisessa humanismissa häiritsee sen ehdottomuus: sen varmuus ihmisen erillisyydestä ja ylivertaisuudesta. Transsendentaalinen humanismi on siten kyvytön tarkastelemaan lajienvälisiä vuorovaikutus- ja riippuvaisuussuhteita millään muilla keinoilla kuin niillä, jotka on jo lujitettu länsimaisiin tieteellisiin (ja mahdollisesti esimerkiksi uskonnollisiin) diskursseihin. Näissä ei-inhimillinen luonto näyttäytyy aineellisten resurssien ja fysikaalisten prosessien alueena, johon ihminen on vapaa suhtautumaan erilaisin tavoin: hyödyntäjänä, merkityksellistäjänä, kaitsijana. Pihlströmin muotoilema transsendentaalinen humanismi on perustaltaan horjumatonta. Hän kirjoittaa:

"[h]umanismi (oikein tulkittuna) on välttämätön ehto sille, että puhe arvoista, merkityksistä ja ihmisen asemasta suhteessa (muuhun) luontoon on ylipäätään mahdollista. Posthumanismikin on tässä mielessä humanismia, jonkinlaista epätoivoista humanismia."

Pihlströmin käyttämä posthumanismiin liittyvä epätoivon retoriikka on kiinnostavaa. Hänhän toteaa myös:

"[k]antilaisesta perspektiivistä erilaiset anti-, post- tai transhumanismin muodot ovat jokseenkin epätoivoisia yrityksiä räpistellä irti inhimillisen ajattelun väistämättömästä ihmiskeskeisyydestä."

Epätoivo liittyykin Pihlströmin mukaan humanismiin ja posthumanismiin kahdella tavalla. Ensinnäkin posthumanismi on (humanistien näkökulmasta) epätoivoista, koska se on filosofinen harha-askel ja jo lähtökohdiltaan mahdotonta. Toiseksi Pihlström kirjoittaa kuitenkin myös epätoivosta, jon$\mathrm{ka}$ humanismin puolustajat valitsevat toivon rinnalle humanismin kehittämisen välineeksi. Tämä epätoivo tarkoittaa Pihlströmin sanoin "liiallisesta välineellisestä ratkaisukeskeisyydestä luopumista”, eli (posthumanistien näkökulmasta) välttämätöntä ymmärrystä ihmisen kykyjen ja mahdollisuuksien vaillinaisuudesta.

Kantilaisen humanismin kehyksessä posthumanistinen ajattelu varmasti näyttäytyy epätoivoisena: ihmiset pyrkivät laajentamaan merkitysprosessien, etiikan ja yhteisöjen alueita ei-inhimillistä kohti ymmärtämättä, että tämä laajentamisen työ kuuluu aina ja välttämättä yksin ihmisille. Posthumanistit itse eivät uskoakseni kuitenkaan tunne epätoivoa oman ajattelunsa väistämättömästä ihmiskeskeisyydestä.He tiedostavat työskentelevänsä kielellä, käsitteillä ja välineillä, jotka ovat ihmisten käytössä, he tietävät viestivänsä ihmisyhteisöissä ja he tiedostavat ihmislajin poikkeuksellisen vallan ja voiman suhteessa muuhun luontoon. Kaiken tämän rinnalla posthumanistit pyrkivät sinnikkäästi tunnistamaan ja jäljittämään niitä moninaisia ei-inhimillisiä semioottisia ja materiaalisia kytköksiä, verkottumisia ja vai- 
kuttumisia, joita inhimilliseen toimintaan on aina liittynyt ja tulee liittymään.

Posthumanistisille ajattelijoille epätoivoisuus jäsentyy nähdäkseni toisin kuin humanisteille. Epätoivo liittyy riittämättömyyteen ja epävarmuuteen oman rajallisuuden edessä: meillä ihmisillä ei ole tarpeeksi tietoa ei-inhimillisten olioiden kyvyistä, vaikutuksista ja voimista, eikä meillä ole käsitteitä ja käytäntöjä huomioida ja rakentaa tietoa ja yhteisöjä, jotka kannattelisivat paremmin ja olisivat kestävämpiä. Tällä tavalla posthumanistien jakama moraalis-tiedollinen epätoivoisuus on hämmentävän samankaltaista sen eettisesti värittyneen epätoivon kanssa, josta Pihlström kirjoittaa humanismiin oleellisesti kuuluvana itsekriittisyytenä. Posthumanistiset tutkijat puhuvat haavoittuvuudesta, kyvyttömyydestä ja vaillinaisuudesta, joilla viitataan ihmisten ja ei-ihmisten sekä näiden muodostamien yhteisöjen eriarvoisuuksiin ja niistä seuraaviin haavoittuvuuksiin sekä tutkimuksen ja tiedontuotannon, käsitteiden ja tutkimuksen osittaisuuteen. Toisaalta posthumanismi liittyy myös filosofiseen perinteeseen, jossa (itse)kritiikin kohteena on erityisesti länsimaisen ihmisen erityisasema suhteessa muihin ihmisyyksiin.

\section{YMPÄRISTÖONGELMAT}

Kysymys epätoivosta liittyy myös ympäristökriisiin, josta on viime aikoina keskusteltu toivon ja toivottomuuden kokemuksiin tai käsitteisiin viitaten. Pihlström tuo tähän keskusteluun merkittävän lisän kytkemällä transsendentaalisen humanismin optimismin tai pessimismin sijaan pragmatistien puolustamaan "meliorismiin", jossa tuleva hyvä on mahdollinen, jos ihmiset tekevät sen eteen työtä. En keksi parempaa lähtökohtaa käsillä olevaan monimutkaiseen tilanteeseen, jossa ympäristöongelmien rinnalla on ratkottava monia muita, esimerkiksi sosiaaliseen eriarvoisuuteen ja yhteiskunnallisiin rakennemuu- toksiin liittyviä ongelmia. Pihlström kirjoittaa: "[e]hkä meillä on metatasolla toivoa nimenomaan oikeanlaiseen toivottomuuteen (ja samalla oikeanlaiseen toivoon) kasvamisesta ja väärän toivon (mutta samalla myös vääränlaisen, nihilistisen toivottomuuden) torjunnasta." Oikeanlainen toivottomuus tarkoittaa Pihlströmille "liiallisesta välineellisestä ratkaisukeskeisyydestä luopumista". Tämä ajatus on rinnastettavissa edellä sivuamiini posthumanistisiin käsityksiin ihmisen läpikotaisesta haavoittuvuudesta ja vaillinaisuudesta.

Haluan nostaa uudelleen esille posthumanismin toimijuus-, valta- ja moraalinäkemyksiä kohtaan esitetyn kritiikin ympäristöongelmien yhteydessä, koska niiden ratkaisijana posthumanismi näyttäytyy kenties kaikkein jakautuneimmin onnistujana tai epäonnistujana. Posthumanistiset ajattelijat (joiksi luen tässä yhteydessä myös esimerkiksi toimijaverkkoteorian tai uusmaterialististen filosofioiden parissa työskentelevät tutkijat ja teoreetikot) lähtevät siitä, että ihmisyhteisön toimintaa on aina tarkasteltava sen aineellisten ja muiden kuin ihmislähtöisten ehtojen ja vaikutusten yhteyksissä. Ympäristöongelmien monimutkaisuus on toki käsitettävissä ja käsiteltävissä ilman vaikkapa ei-inhimillistä toimijuutta, mutta tällaisten käsitteiden tarkoitus on tarttua maailmaan arvaamattomampana, verkottuneempana ja eloisampana. Siten posthumanistinen ympäristöetiikkakin perustuu eliölajien hierarkian epäilemiselle ja moraalisen ajattelun ulottamiselle ihmisen ja inhimillisen ulkopuolelle.

Posthumanismin sekavuutta arvostellessaan Pihlström liittyy melko laajaankin joukkoon ajattelijoita, jotka pitävät posthumanismia kykenemättömänä tai jopa haitallisena filosofiana esimerkiksi ympäristökriisiin vastaamisen kannalta. Edellä jo lainaamani Ruuska, Wilén ja Heikkurinen (2019, 142) arvostelevat Andreas Malmin ajatuksiin nojaten "hybridiajatteluksi" nimettyä toimijaverkkoteoriaa seuraavasti: "hybridiajattelun mukaan on vaikea sanoa, mikä aiheuttaa il- 
mastonmuutoksen nimenomaan sen takia, ettei ihmiskunnan toimia, kuten esimerkiksi öljy-yhtiöiden toimintaa, pyritä systemaattisesti erottelemaan muusta luonnosta”. Kirjoittajat myöntävät kärjistävänsä, mistä on toden totta kysymys. Esimerkiksi Bruno Latour, yksi toimijaverkkoteorian kehittäjistä, rakentaa Politics of Nature -teoksessaan (2004) filosofista mallia ihmisten ja ei-ihmisten yhteisölle, jolla on poliittiset, tiedolliset ja moraaliset välineet koko yhteisölle (eli sen ei-inhimillisillekin jäsenille) haitallisten tekijöiden ulossulkemiseksi tai hylkäämiseksi.

Antroposeenikeskustelun puitteissa posthumanismin ristiriitaisuuksista ja vahingollisuudesta ovat kirjoittaneet esimerkiksi Alf Hornborg ja Clive Hamilton. Hornborg korostaa toimijuuden tarkoituksellisuutta ja intentionaalisuutta: toimijuutta on vain tuntoisilla, kommunikointiin kykenevillä subjekteilla, joiksi Hornborg kuitenkin mieltää kaikenlaiset elolliset olennot. Elottomat oliot ovat objekteja, ja niillä voi olla monenlaisia vaikutuksia mutta ei milloinkaan toimijuutta. (Hornborg 2019, 180-182.) Hornborg (2019, 205-207) hyökkää muun muassa Bruno Latouria vastaan samoin syin kuin Ruuska, Wilén ja Heikkurinen: ei-inhimillisiä toimijuuksia tarkastellessaan Latour ja vastaavat posthumanistiset ajattelijat hämärtävät ihmisen toimijuutta ja ainutlaatuista vastuullisuutta. Hornborg (2019, 193-199) kritisoi huomattavan piikikkäästi kuitenkin myös posthumanististen ajattelijoiden, erityisesti Donna Harawayn ja Anna Lowenhaupt Tsingin, tyyliä ja tapaa kirjoittaa. Akateemisen tarkkuuden puute näyttää olevan Hornborgille yhtä suuri huolenaihe kuin esitettyjen ajatusten ongelmallisuus tai ristiriitaisuus.

Samansuuntaista kritiikkiä posthumanismiin kohdistaa Clive Hamilton, jonka mukaan posthumanistinen ajattelu poistaa toimijuutta ihmisiltä ja siirtää sitä ei-inhimillisille olioille tai ilmiöille (Hamilton 2017, 91-95). Hamiltonin mukaan antroposeeni ilmiönä osoittaa, että ihmiset erottuvat kaikista muista elämän- muodoista, ja että antroposeenin aikana todella vastuullinen filosofia perustuu välttämättä ymmärrykselle ihmisen erityislaatuisuudesta. (Hamilton 2017, 98-101.) Kysyä voi kuitenkin, viekö ei-inhimillisen toimijuuden tiedostaminen toimijuutta ihmisiltä. Hamiltonin oman, mielestäni erinomaisen, muotoilun mukaan maapallolla vaikuttaa tällä hetkellä sekä inhimillisiä (teknologisia, luonnonvaroja kuluttavia, jne.) että ei-inhimillisiä (säässä, ilmastossa, merivirroissa jne. ilmeneviä) voimia enemmän kuin koskaan ennen (Hamilton 2017, 45). Kyse ei olekaan nollasummapelistä.

Lienee selvää että Homo sapiens on se laji, jolla on kattavin ymmärrys ja myös vastuu ekokriisistä. Ihmisen käytössä ovat ensinnäkin ne teknologiat ja käsitteelliset välineet, joilla maapallosysteemin häiriöitä voidaan todentaa ja hahmottaa. Toiseksi tiedetään, että tämä häiriötila myös johtuu ihmisen toiminnasta. Mielestäni ajatus ei-inhimillisestä toimijuudesta tai ajatus lajien hierarkiaa kyseenalaistavasta etiikasta ei haasta tai horjuta näitä ihmistä koskevia selvyyksiä. Ei ihmisen moraalinen vastuu ei-inhimillisestä luonnosta murene, jos ihmiskeskeisen moraalin perustoja haastetaan.

Pihlströmin ilmastohumanismi perustuu nimenomaan ihmiskeskeisyydelle. Hän kirjoittaa: "[a]rvoja ja merkityksiä voi olla vain ihmiselle, ihmisen maailmassa. Siksi vain ihminen voi elämässään joutua arvojen ja merkitysten katoamisen uhkaamaksi." Edelleen, "tuntemistamme olennoista vain ihminen elää normatiivisessa avaruudessa, maailmassa, jossa on ylipäänsä mahdollista tehdä oikean ja väärän tai hyvän ja pahan välisiä erotteluja”. Ymmärrän Pihlströmin näkemysten logiikan, mutta haluaisin silti väittää, etteivät eettisen järjestelmän sisäinen koherenssi ja sen tietynlainen (pitkälle filosofiselle traditiolle ja sen jatkuvalle vahvistukselle perustuva) järkeenkäypyys tee siitä ainoaa oikeaa. Kuten Pihlströmkin toteaa, posthumanistinen kritiikki on kohdistunut humanismin tai humanistisen etiikan ihmiskeskeisyyteen siksi, että se on vaikutuksiltaan epäonnistunutta. Ihmiseen 
keskittyminen jonakin annettuna (vrt. transsendentaalisen määritelmä) tuottaa ihmiskeskeisyyttä. Ihmiskeskeistä etiikkaa voi hienosäätää antamalla (lainaan jälleen Pihlströmiä) "ei-inhimilliselle luonnolle sellaista arvoa, joka ylittää pelkän välineellisyyden”, mutta tämä ei posthumanismista näkökulmasta katsoen korjaa perusongelmaa, ihmisen erottamista ja korottamista muusta luonnosta. Tähän liittyen on yllättävää, että Pihlström kuitenkin esittää humanismin olevan "järkevästi tulkittuna" antiessentialistista - humanismi ei siis lukitse ihmisen olemusta itsessään, eikä se lukitse edes ihmisen ja eläimen välistä eroa. Mainittu ero voi olla "pelkkä aste-ero - ja sellaisenaan jatkuvasti muuttuva ja uudelleen tulkittavissa". Kuten Inkeri Koskinen omassa kommentaarissaan toteaa, tässä Pihlströmin humanismi alkaa saada huomattavan posthumanistisia sävyjä.

Pihlströmin esiin nostaman antroposeenin käsitteen tarkasteleminen humanismin yhteydessä on mielestäni vaikeaa siitä yksinkertaisesta syystä, että antroposeenin käsitteelle ei ole olemassa yhteisesti jaettua merkitystä. Antroposeenin käsite ei välttämättä sisällä normatiivisia merkityksiä ja se saattaa joissakin keskusteluissa viitata ihmisen aikaan jopa hyvänä asiana (ks. esim. Heise 2016, 206-208). Pihlström kritisoi faktuaalisuuden ja normatiivisuuden jännitettä antroposeenikeskustelussa. Huomio on kohdallinen: antroposeeni on ehdotettu epookin nimi ja siten periaatteessa luonnontieteellinen käsite, mutta samalla se on uusi nimitys ihmislähtöisille maapallojärjestelmää epävakaampaan tilaan ajaville muutoksille. Sen sijaan en ymmärrä seuraavaa Pihlströmin muotoilemaa kritiikkiä: "[t]ämä on post- ja antihumanismin ongelma yleisemminkin: faktuaalinen kuvaus jostakin ihmisen aiheuttamasta ongelmasta (josta humanisti voi hyvin olla samaa mieltä) naamioi normatiivisen väitteen ihmisen toiminnan 'vääryydestä.” Minulle jää epäselväksi, mitä naamiointi tässä tarkoittaa - sitäkö, että ihmisen aiheuttamat ongelmat käännetään kokonaisuudessaan todisteeksi ihmisen toiminnan kokonaisvaltai- sesta vääryydestä? En tunnista tätä yksin posthumanistien synniksi. Pihlström toteaa myös, ettei "ihmisen erityisasemasta päästä eroon antroposeenin kaltaisilla käsitteellisillä innovaatioilla”. Posthumanisteille tämä on tuskin ollut tarkoitustaan, vaikka antroposeenia on tulkittu myös aikana, jolloin ei-inhimilliset pakottautuvat ihmisten ajateltaviksi (Morton 2013; Latour 2011).

Ympäristökysymysten yhteydessä Pihlström nostaa myös esiin kysymykset fasismista ja totalitarismista. Tämänhetkisessä tilanteessa, kun erilaiset talouden globaalit järjestelmät ja tuotantomuodot ovat osoittautuneet heikoiksi tai haitallisiksi sekä ihmisten että luonnon kannalta, on laaja-alaisten käytännöllisten (poliittiseen ja taloudelliseen ohjaukseen perustuvien) ja filosofisten (vaihtoehtoisten yhteisöä, etiikkaa tms. ehdottavien) korjausliikkeiden muotoilu ja ehdottaminen yhä vaikeaa. Vähänkään kokonaisvaltaisemmin kehitellyt vaihtoehdot leimataan herkästi uusiksi suuriksi kertomuksiksi, keskusvetoisiksi ja siksi mahdollisesti vaarallisiksi järjestyksiksi tai aatejärjestelmiksi, joiden kritisoimiseksi ja murentamiseksi nykyisetkin ihmistieteilijät yhä tuntevat työskentelevänsä. En olekaan yllättynyt siitä, että Pihlström varoittelee posthumanisteja ja ekologisen realismin (Heikkurinen et al. 2019) kannattajia totalitarismin ja ekofasismin vaaroista. Haluaisin kuitenkin kysyä, miksi jokainen kokonaisvaltaisuuteen tai yhteisen suunnan hahmottamiseen pyrkivä ajattelutapa on tässä ekologisessa, taloudellisessa, poliittisessa ja sosiaalisessa tilanteessa arvosteltavissa fasistiseksi. Tämä leimaava ele alkaa mielestäni menettää uskottavuuttaan tilanteessa, jossa suunnan on pakko muuttua nopeasti ja laaja-alaisesti.

Hämmennystäni lisää Pihlströmin tapa erotella moraalisesti arvokkaita olioita toisistaan: "ihminen on arvokas laadullisesti erilaisella tavalla kuin mikään muu tuntemamme olento tai tällaisten olentojen kokonaisuus." Ymmärrän, että transsendentaalisessa humanismissa ihmisarvo on kiistämätön. Totalita- 
rismiin ja ekofasismin ideologisissa kehyksissä haluaisin kuitenkin kysyä, miksi minun tulisi suhtautua neutraalisti ja jopa hyväksyvästi ilmaukseen "arvokas laadullisesti erilaisella tavalla”. Miksi minun tulisi epäillä ekologista holismia vaaralliseksi totalitarismiksi, mutta samalla hyväksyä laatuun perustuvat arvoerot eri lajien välillä - ikään kuin tällaiseen spesistiseen hierarkiaan ei liittyisi samoja totalitarisoivia eleitä? Intersektionaalinen feminismi on vakuuttavasti osoittanut, että sorron mekanismit ihmisyhteisöissä ja lajienvälisissä suhteissa kytkeytyvät yhteen.

\section{ELÄIMEN AJATTELEMISESTA}

Humanismin poliittista ulottuvuutta Pihlström selvittelee totalitarismin ja ihmisen eläimellistämisen uhkien kautta. Humanismi nimittäin on Pihlströmin mukaan ainoa keino taistella ihmisen eläimellistämistä vastaan: "vain humanismin näkökulmasta voidaan kritisoida - tai vahvemmin paheksua ja tuomita - pyrkimykset eläimellistää ihminen (tai jokin ihmisryhmä, kuten juutalaiset holokaustissa), ja tämän kriittisen mahdollisuuden ylläpitämiseksi myös humanismia on pidettävä yllä.” Voin vastata tähän kritiikkiin toistamalla itseäni: posthumanistisessakin ajattelussa on eettiset ulottuvuutensa ja käsitteelliset välineensä, jotka perustuvat hierarkian sijaan kaiken eroihin perustuvan väkivallan ja sorron välttämiseen. Näitä ulottuvuuksia ja käsitteitä voi näkökulmasta riippuen joko pitää pohjimmiltaan humanistisina (posthumanismi humanismin itsekriittisenä tarkennuksena tai humanismin kokeellisena ulottuvuutena), tai niitä voi pitää erheellisenä kategorioiden sotkemisena (posthumanismi kyvyttömyytenä käsitellä lajieroja, valtaa, ihmisen erityisyyttä), mutta nämä kannat eivät riitä kiistämään posthumanismin eettisiä ulottuvuuksia.

Kirjoituksessaan Pihlström lukitsee näkemyksensä ihmisen ja eläimen ratkaisevasta erosta monin eri tavoin. Vaikka ihmisillä ja muilla lajeilla on erilaisia hätkähdyttäviäkin yhteneväisyyksiä, joita opitaan tieteellisen tutkimuksen kehittyessä yhä paremmin tuntemaan, kokonaisuudessaan ihmislaji on kuitenkin omalaatuinen. Humanismin onkin "korostettava holismia, inhimillisen elämän kokonaisuuden eroa kaikkien muiden elävien olentojen elämistä ja elämäntavoista”. Tällaisessa ajattelussa ihmisen ja eläimen ero ei Pihlströmin mukaan ole paikannettavissa mihinkään tiettyyn asiaan (esimerkiksi kommunikointiin), koska eron paikka on kaikkialla, ihmisen elämässä kokonaisuudessaan omanlaisenaan, eläinten elämästä erottuvana. Ihmisen eläimellistämisen kauhistuttavuuskin selittyy juuri tällä ihmisen ja eläimen paikantumattomalla, kokonaisvaltaisella erolla. Vaikka myönnänkin olevani epävarma ihmisen ja muiden eläinten eroista, niiden paikantamisesta, kokonaisvaltaisuudesta sekä erojen lukitsemisen seurauksista, Pihlströmin tapa selittää ihmisen eläimellistämisen moraalinen kauhu ihmisen ja eläimen välisellä paikantumattomalla erolla vetoaa.

Suurella mielenkiinnolla luin myös Pihlströmin ajatuksia eläimistä ja merkityksistä. Hän esimerkiksi kirjoittaa:

\footnotetext{
"Myös puhe ei-inhimillisen olemassaolon merkityksestä (tai merkityksen puuttumisesta) on kirjaimellisesti tulkittuna vailla järkevää sisältöä, koska vain ihmisen maailma on merkitysten maailma. Siksi vain ihmisen maailma voi menettää merkityksellisyytensä ja tulla absurdiksi. Eläimelle mikään ei voi olla absurdia (eikä ei-absurdia), koska eläimillä ei ole merkityksiäkään - ellei sitten jonkinlaisena alkeisversiona merkitysten puutteesta pidetä vaikkapa sellaista tilannetta, jossa eläin kärsii joutuessaan lajityypillisten elinolosuhteidensa ulkopuolelle. Tällöinkään ei kuitenkaan ole osuvaa puhua merkityksistä sellaisessa vahvassa ja syvässä mielessä, jossa sanomme ihmisen maailmassa olevan merkityksiä."
} 
Koska eläimen kyvyt ovat keskeinen kysymys transsendentaalisessa humanismissa, haluan viivähtää näissä merkityksiä koskevissa väitteissä. Ensinnäkin olemassaolon merkitys (merkitys arvona, merkitys annettuna tai koettuna tärkeytenä, merkitys merkittävyytenä) ja olemassaolo merkitysten (merkkien, merkkisuhteiden) maailmassa ovat nähdäkseni kaksi eri asiaa. Vaikka ajateltaisiin, että "vain ihmisen maailma on merkitysten maailma", tästä ei kai seuraa, että väite ei-inhimillisen olemassaolon merkityksestä olisi vailla järkevää sisältöä? Merkityksen käsite uhkaa hajota kahtaalle, merkittävyyden ja merkkisuhteiden alueille. En ole aivan varma siitä, mitä Pihlström tarkoittaa absurdilla - todennäköisesti jonkinlaista täydellistä mielettömyyttä,joka on hänen mukaansa eläimen kokemuksen ulkopuolella.

Yllä olevassa lainauksessa esitetty esimerkkitilanne, jossa eläin joutuu lajityypillisten olosuhteidensa ulkopuolelle, johdattaa joka tapauksessa merkityksen käsitteen ytimeen. Eestiläis-baltialaisen etologin Jakob von Uexküllin (1864-1944) merkkiteoriassa - jonka taustalla muuten on osaltaan myös Immanuel Kantin filosofia - merkitys on biologinen ilmiö, joka perustuu organismin ja ympäristön yhteensopivuuteen eli siihen, että organismille on kehittynyt kyky lukea ympäristöään ja vaikuttaa siihen. Pihlströmin nimitys "alkeisversio" viitannee aineenvaihdunnan kaltaisiin biologisiin prosesseihin. Uexküllin teorian puitteissa tällaista tasoa voi kutsua vegetatiiviseksi semioottiseksi kynnysalueeksi, kuten biosemiootikko Kalevi Kull (2009) on esittänyt. Kull erottaa tästä alueesta animaalisen (esimerkiksi eläinyksilöiden välisen kommunikaation kattavan) ja kulttuurisen (vain ihmisille kuuluvan) semioottisen kynnysalueen. Korkeimmalle ja ainutlaatuisimmaksi Kull nostaa Pihlströmin tavoin kulttuurisen alueen.

Keskustelu semiosiksen tasoista ja inhimillisen tai kulttuurisen semiosiksen erityislaadusta ilmentää samanlaista järjestelyn ja eronteon elettä kuin etiikan rajaaminen ihmislajin asiaksi. Esimerkiksi edellä antroposeenikeskustelun yhteydessä mainittu Alf Hornborg (2019, 182-186) tekee laadullisen eron ihmisten ja eläinten semiosiksen välillä. Humanistinen (tai kantilainen) traditio tuottaa järjestystä ja hierarkiaa sekä etiikkaan että semiotiikkaan. Kiinnostavasti monet posthumanistisiksi luonnehdittavat tutkijat ovat soveltaneet Uexküllin ajatuksia humanistista hierarkiaa haastavilla tavoilla (ks. esim. Parikka 2010; Broglio 2011). Toisaalta myös biosemiotiikka on aiempaa avoimempi posthumanistisille tulkinnoille semiosiksesta inhimillisen ja ei-inhimillisen rajapinnoilla. Ekosemiootikko Timo Maran (2014, 153-154) kirjoittaa:

"biosemiotics holds the understanding that there is a typological difference between the semiotic capacities of matter, plants, animals, and humans. In analyzing contemporary, human-altered environments, however, these distinctions have become blurred and unreliable."

Pihlström toteaa, että "[i]hmiselämän tuhoamisen kauhistuttavuus liittyykin juuri potentiaalisesti rajattoman merkityksellisyyden tuhoamiseen.” Tässä yhteydessä merkityksellisyys liittyy pikemminkin arvoihin kuin semiosikseen, mutta mikäli olen oikeassa, transsendentaalisessa humanismissa nämä liittyvät toisiinsa. Semiosiksen monitasoisuus kytkeytyy elimellisesti merkityksellisyyteen arvokkuutena.

Huoli merkityksellisyyden tuhoutumisesta ei kuitenkaan liity vain ihmiseen. Eestiläinen luonnontieteilijä Ivar Puura (2013; ks. myös Maran 2013) on varoittanut meitä luonnon moninaisuuden köyhtymiseen liittyvästä merkitysyhteyksien ja niiden ehtojen häviämisestä. Puuran nimi tälle tilanteelle on semiocide: kokonainen merkityssuhteiden ja niitä ylläpitävien organismien korvaamaton verkosto tuhoutuu. Tällaiset tuhotapahtumat ovat kauhistuttavia myös ei-inhimillisissä yhteyksissä ja kehyksissä. 
Luonnon ja kulttuurin rajoja piirtäessäänkin bio-, eko- ja zoosemioottiset näkökulmat avartavat filosofista keskustelua eläimistä, eläimyydestä ja eläimen käsitteestä (näiden käsitteiden ongelmista ks. esim. Aaltola 2013). Ihmisen ja eläimen kokonaisvaltaisesta erosta Pihlström tarjoaa myös seuraavan muotoilun: "[e]läinten elämä on suljettua ja valmista, ihmisen radikaalisti vapaata, avointa uudelle." Posthumanismia hän syyttää vaarasta "kaventaa tätä vapautta ja avoimuutta biologisen - tai muun, esimerkiksi sosiologisen - reduktionismin suuntaan." Pihlström kirjoittaa vapaudesta vakuuttavasti ehdottaen esimerkiksi, että ihmisen tärkein vapaus on vapaus olla vapaa. En itse halua sellaista posthumanismia, joka kaventaisi ihmisen vapauksia esimerkiksi biologiaan vedoten, mutta en myöskään halua sellaista humanismia, joka asettaa eläimet lajin perusteella suljetun ja valmiin filosofisiin kategorioihin. Pelkään (ja tiedän), että filosofiasta on lyhyt matka käytäntöihin, joissa eläinten elämä konkreettisesti on suljettua ja valmista.

\section{LOPUKSI}

Minulle posthumanismi merkitsee käsitteellistä, menetelmällistä ja eettistä tilaa humanismin ja humanistisen ihmiskuvan ja luontokäsityksen haastamiseen. En ajattele, että posthumanismi puolustaisi itsekritiikittömästi ja varauksetta mitään tiettyä kantaa ihmisen ja muiden olioiden suhteista. Posthumanismin tarkoitus ja tehtävä on pikemminkin kysyä perusteita hierarkioille, erotteluille ja lajeja koskeville varmuuksille (esimerkiksi varmuudelle siitä, että ihmisten ja ei-ihmisten välillä on ratkaiseva, lajienvälistä arvoasteikkoa tuottava ero ja katkos). Pihlström kirjoittaa: "[n]iin historiallisesti muokkautuvaa kuin humanismi onkin, se ei trivialisoidu sisällyksettömäksi: humanistin on nähdäkseni mahdotonta yhtyä esimerkiksi sellaisiin 'luontokeskeisiin' ajattelutapoihin, jotka korostavat kaikkien eliölajien yhtäläistä arvoa.” Ymmärrän, että Pihlström väistelee tässä humanismin liiallista limittymistä posthumanismin kanssa, mutta minusta on silti ongelmallista, että hänen esimerkkinsä sisällyksettömästä ajattelutavasta on nimenomaan näkemys eliölajien yhtäläisestä arvosta. Kuinka mikään arvoja koskeva kanta voisi olla sisällyksetön?

Pihlström myös toteaa, että "[t]odellinen humanisti on jatkuvasti valmis ylittämään aiemman humanisminsa." Olen itse pysytellyt posthumanistisen ajattelun parissa juuri tähän luottaen: posthumanistinkin on oltava valmis ylittämään aiempi posthumanisminsa. Tulkitsen ylittämisen jatkuvaksi korjausliikkeeksi ja itsekritiikiksi mutta myös kiinnostavien ja hedelmällisten ideoiden kehittämiseksi ja laajentamiseksi. Kysymys ihmisen ja muun luonnon suhteista pysyy transsendentaalisessa humanismissa lukittuna järjestykseen, rationaalisuuteen ja traditioon vedoten, kun tuon suhteen pitäisi viimeistään nyt, globaalin ympäristökriisin aikana, aueta koeteltavaksi ja uudelleen neuvoteltavaksi.

\section{KIITOKSET}

Olen tukeutunut kirjoituksessani kollegoideni Katri Abolaisen, Kaisa Kurikan, Lea Rojolan ja Helinä Ä̈̈rin asiantuntemukseen sekä heidän tulossa oleviin julkaisuibinsa Karen Baradin toimijuusrealismin (Rojola, Abolainen), Gilles Deleuzen ja Félix Guattarin fllosofian (Kurikka) ja intersektionaalisen feminismin (Ä̈̈ri) eettisistä ulottuvuuksista. Kiitän myös Ari Korhosta ja Tero Toivasta heidän erinomaisista kommenteistaan kirjoitukseeni. 


\section{KIRJALLISUUS}

Aaltola, Elisa (2013) (toim.). Johdatus eläinfilosofiaan. Suom. Johanna Koskinen. Helsinki: Gaudeamus.

Broglio, Ron (2011). Surface Encounters. Thinking with Animals and Art. Minneapolis \& London: University of Minnesota Press.

Hamilton, Clive (2017). Defiant Earth. The Fate of Humans in the Anthropocene. Cambridge, UK: Polity Press.

Heise, Ursula K. (2016). Imagining Extinction. The Cultural Meanings of Endangered Species. Chicago \& London: The University of Chicago Press.

Hornborg, Alf (2019). Nature, Society, and Justice in the Anthropocene. Unraveling the Money-Energy-Technology Complex. Cambridge, UK: Cambridge University Press.

Koskinen, Inkeri (2020)."Humanismi, nihilismi ja eläin." Tiede Eे edistys 1/2020, 53-55.

Kull, Kalevi (2009). "Vegetative, animal, and cultural semiosis: the semiotic threshold zones." Cognitive Semiotics 4/2009, 8-27.

Latour, Bruno (2004). Politics of Nature. How to Bring the Sciences into Democracy. Transl. Catherine Porter. Cambridge, Massachusetts \& London, England: Harvard University Press.

Latour, Bruno (2011). "Waiting for Gaia. Composing the common world through arts and politics." A lecture at the French institute, London, November 2011 for the launching of SPEAP (the Sciences Po program in arts and politics). Luettavissa osoitteessa http://www. bruno-latour.fr/node/446.

Lummaa, Karoliina (2010). Poliittinen siivekäs. Lintujen konkreettisuus suomalaisessa 1970-luvun ympäristörunoudessa. Jyväskylä: Nykykulttuurin tutkimuskeskus, Jyväskylän yliopisto.

Lummaa, Karoliina \& Lea Rojola (toim.) (2014). Posthumanismi. Turku: Eetos.

Maran, Timo (2013). "Enchantment of the past and semiocide. Remembering Ivar Puura." Sign Systems Studies 41:1, 146-149.

Maran, Timo (2014). "Semiotization of matter: a hybrid zone between biosemiotics and material ecocriticism." Teoksessa Material Ecocriticism, toim. Serenella Iovino \& Serpil Oppermann. Bloomington, Indiana: Indiana University Press. 141-154.
Morton, Timothy (2013). Hyperobjects. Philosophy and Ecology after the End of the World. Minneapolis \& London: University of Minnesota Press.

Parikka, Jussi (2010). Insect Media. An Archaeology of Animals and Technology. Minneapolis \& London: University of Minnesota Press.

Pihlström, Sami (2020). "Transsendentaalinen humanismi." Tiede छ edistys $1 / 2020,38-52$.

Puura, Ivar (2013). "Nature in our memory." Sign Systems Studies 41:1, 150-153.

Ruuska, Toni, Wilén, Kristoffer ja Heikkurinen, Pasi (2019). "Ihminen osana luontoa. Ekologinen realismi ja kestävä taloudellinen organisoituminen." Tiede $\mathcal{E}^{\circ}$ edistys 2/2019, 135-149. 